\title{
O gênero da modernidade e o gênero da teologia: impactos socioculturais do pensamento masculino ${ }^{1}$
}

Neiva Furlin ${ }^{2}$

\begin{abstract}
Resumo
A partir da perspectiva sociocultural e da crítica feminista, este trabalho evidencia que a teologia histórica, a ciência moderna e outras narrativas sobre a modernidade tiveram em comum a perspectiva androcêntrica do conhecimento. Sob a inspiração da obra de Rita Felski, The Gender of Modernity, construímos uma analogia entre o pensamento teológico e os relatos da modernidade, mostrando como o conhecimento masculino produziu representações simbólicas que trouxeram impactos na organização social e eclesial. É um pensamento com poder performativo, que universalizou e institucionalizou estruturas hierárquicas e androcêntricas; invisibilizou as experiências femininas na condução dos processos históricos; produziu e legitimou a desigualdade de gênero e a posição subalterna das mulheres, no interior das instituições socioeclesiais.
\end{abstract}

Palavras-chave: gênero - modernidade - teologia - crítica feminista - pensamento masculino.

\begin{abstract}
Based on a sociocultural perspective and feminist criticism, this article shows that historical theology, modern science and other narratives on modernity always had in common the androcentric perspective of knowledge. Inspirated by Rita Felski's work, The Gender of Modernity, it constructs an analogy between theological thinking and accounts of modernity, showing how the male knowledge produced symbolic representations that gained impacts on social and ecclesial organization. This thinking has performative power and universalized and institutionalized hierarchical and andocentric structures, turned invisible women's experiences in the course of the historical processes, and also produced and legalized gender inequality and the subordinate position of women within social and ecclesial institutions.
\end{abstract}

Key-words: gender - modernity - theology - feminist criticism - male thinking.

Fecha de recepción: 14 de mayo del 2013

Fecha de aprobación: 5 de agosto del 2014

Esse artigo é uma versão ampliada do trabalho discutido no XXVIII Congresso Internacional da Associação LatinoAmericana de Sociologia (ALAS), realizado em setembro de 2011, na cidade Recife-PE.

2 Doutora em Sociologia pela UFPR (2014), com doutorado sanduíche pelo Centro de Investigaciones Interdisciplinarias en Ciencias y Humanidades (CEIICH) da Universidade Nacional Autónoma de México (UNAM) (2012). É membro do Núcleo Interdisciplinar de Estudos de Gênero da UFPR. E-mail: nfurlin@yahoo.com.br. 


\section{INTRODUÇÃO}

A teoria feminista, cuja origem aparece vinculada ao movimento feminista, que emergiu no contexto da revolução contracultural, na década de 1960, representou no seio dos movimentos sociais e no meio acadêmico uma ruptura radical com a cultura herdada e construída sob a visão masculina. Cultura essa que havia reproduzido a dominação masculina e a invisibilidade da contribuição das mulheres à sociedade, à história, à cultura e à vida política, colocando-as fora dos processos históricos da modernidade.

Atualmente, a teoria feminista e a abordagem analítica de gênero possuem legitimidade acadêmica e se configuram como um novo paradigma de análise e compreensão da sociedade contemporânea, integrando o grande rol das ferramentas epistemológicas que orientam a produção do conhecimento. Assim, a penetração da crítica feminista nas diferentes áreas do conhecimento possibilitou questionar o pensamento androcêntrico e a desconstruir representações que privilegiaram historicamente a supremacia do sujeito masculino, nos processos socioculturais.

Este trabalho pretende fazer uma espécie de comparação entre as representações de gênero presente na literatura da modernidade, analisada pela feminista Rita Felski, na obra The Gender of modernity, com as construídas pelo pensamento da teologia católica tradicional ${ }^{3}$, no intuito de evidenciar como a perspectiva masculina do conhecimento produziu impactos na produção de subjetividades e na organização social e eclesial.

Com o advento da modernidade o pensamento teológico passou a ser visto como um pensamento arcaico, que regia a velha sociedade e se opunha à modernidade emergente, uma vez que tal pensamento era fundado na hierarquia e na tradição. A modernidade é, aqui, compreendida como um modo de civilização que se desenvolveu na Europa Ocidental a partir do século XVI, com o Humanismo Renascentista e a Reforma Protestante. Contudo, é no pensamento empirista, racionalista e iluminista dos séculos XVII e XVIII que ela encontrou seus fundamentos filosóficos e políticos (Higuet, 2005). A modernidade, mais que um período histórico do ocidente, que abrange os séculos XVI a XIX, coloca em cena um conceito técnico e científico (racionalidade matemática e instrumental, revolução industrial), um conceito político (revolução democrática e Estado absoluto e centralizado) e um conceito psicológico (emergência da consciência individual e do domínio privado) (Higuet, 2005: 11). Já, em Rita Felski (1995), a modernidade é um período histórico, no qual está incluído o processo de modernização (desenvolvimento da ciência e inovação tecnológica, industrialização da produção, urbanização, expansão do mercado capitalista e desenvolvimento do Estado Nação) e o modernismo (forma específica de produção artística que se desenvolveu na América Latina e na Europa no século XIX). Um período que inclui, também, uma distinção da filosofia de vida entre as sociedades tradicionais estruturadas em torno

\footnotetext{
3 Aqui nos referimos, especificamente, às representações de gênero presente no discurso teológico católico. Porém, vale lembrar que essa realidade também pode ser constatada em teologias de outras confissões religiosas.
} 
da onipresença e da autoridade divina e o moderno universo secularizado, construído sobre a individualidade e subjetividade autoconsciente. Vale lembrar que é neste contexto que a separação entre o Estado e a Igreja se torna uma questão civilizacional, central no debate da modernidade política.

Desse modo, a sociedade moderna, marcada pela racionalidade e a emancipação do indivíduo, se consolidava em uma relação de oposição aos fardos das tradições e das hierarquias fixas e naturalizadas. A tradição e a hierarquia foram substituídas por outros valores, como a igualdade e a liberdade do indivíduo, que se tornaram fundamentais para o processo de consolidação do Estado moderno e democrático. Esses valores da modernidade foram incorporados no pensamento teológico católico ${ }^{4}$ somente na década de 1960, sob a influência do Concílio Vaticano $\|^{5}$, época em que a teologia se afirma como uma ciência humana de perspectiva hermenêutica, com o objetivo de desvelar o sentido último e transcendente da vida humana. Para isso, a teologia busca dialogar com as ciências modernas, exatas e humanas, no sentido de crítica e de estímulo mútuo, em vista da concretização do projeto emancipatório, que é o sentido último de toda a ciência. Entretanto, a especificidade da teologia, segundo o teólogo Luiz Carlos Susin (2006: 557), reside no fato de se constituir um saber, "cuja racionalidade depende da experiência da fé".

Assim sendo, o objetivo deste trabalho não é evidenciar até que ponto a teologia incluiu ou não os valores da modernidade em seus discursos e nem como ocorreu o seu diálogo com as ciências modernas, mas, a partir de uma perspectiva sociocultural e da crítica feminista, evidenciar que a teologia histórica e tradicional, considerada um pensamento arcaico, no contexto da modernidade emergente ${ }^{6}$, sempre teve algo em comum com a ciência moderna ${ }^{7}$ e com outras formas de narrativas sobre a modernidade. Essa característica comum se refere à perspectiva androcêntrica do conhecimento, cuja caracterização tem sido uma construção dos estudos feministas para ser referir aos saberes produzidos unicamente do ponto de vista dos valores do universo masculino, baseado em uma cultura patriarcal, que produziu efeitos negativos para as subjetividades femininas. Trata-se de um conhecimento que construiu determinadas representações simbólicas de gênero, produzindo impactos socioculturais, tais como: a universalização e a institucionalização de estruturas sociais hierárquicas e androcêntricas, a invisibilidade das experiências femininas e de outros sujeitos na

4 Como toda a ciência, a teologia também tem seu objeto de estudo que é a figura de Deus. Entretanto, como não é possível estudar diretamente um objeto que não se pode ver ou tocar, estuda-se Deus a partir da sua revelação. No cristianismo isso se dá por meio da revelação de Deus na história Bíblica. No sentido Hegeliano, a teologia é o estudo das manifestações sociais de grupos em relação às divindades.

5 O Concílio do Vaticano Il foi realizado em Roma nos anos de 1962 a 1965. É uma espécie de assembleia mundial que reúne Bispos de todos os países, em que são tomadas as principais decisões da Igreja Católica.

6 Enquanto a teologia foi considerada um discurso arcaico por estar fundada na tradição e na hierarquia, Rita Felsk (1995) menciona que nos discursos sobre a modernidade a figura feminina era quem representava o "antimoderno", o arcaico, o primitivo, já que as esferas ou as atividades identificadas como femininas, vinculadas ao espaço privado -no qual família, tradição, criação dos filhos, etc.- foram esvaziadas de historicidade, nos processos de modernização.

7 De acordo com Chassot (2009: 20), "a religião e a ciência ocupam o mesmo espaço: o espaço do pensamento humano". 
condução dos processos históricos, a legitimidade da desigualdade de gênero e a posição subalterna das mulheres, no interior das instituições sociais.

Nesse estudo, quando nos remetemos ao gênero, estamos compreendendo-o como uma construção histórica, dinâmica, relacional e contextual, em que as relações entre homens e mulheres, os discursos e as representações dessas relações estão em constantes mudanças, o que supõe que as identidades de gênero estão sempre se constituindo, são instáveis e, portanto, passíveis de transformação, em contextos de mudanças culturais e em momentos históricos distintos Louro, 1999). Assim, uma das marcas significativas dos estudos de gênero, nos anos de 1980, foi o fato de este incorporar a dimensão do discurso, das representações culturais e das relações de poder na construção do gênero. Essa novidade aparece conectada com as discussões filosóficas do pós-estruturalismo, que se fundam na linguagem e nas ideias de construção e desconstrução.

Desse modo, entre tantos desdobramentos dos estudos de gênero ${ }^{8}$ assumimos a definição de Scott (1990), que enfatiza a existência de uma conexão entre gênero e poder. Para essa autora, o núcleo essencial do conceito de gênero se encontra na relação entre duas proposições, "o gênero é um elemento constitutivo das relações sociais baseado nas diferenças percebidas entre os sexos, e o gênero é uma forma primeira de significar as relações de poder" (Scott 1990: 14) A sua noção de gênero inclui quatro elementos que operam simultaneamente: os símbolos culturalmente disponíveis que evocam representações simbólicas; os conceitos normativos que evidenciam as interpretações do sentido dos símbolos; a noção de política com referência às instituições e à organização social, que permite desvendar a natureza dos discursos ou a repressão que produz a permanência de uma representação binária de gênero; a identidade subjetiva.

Nesse sentido, a noção de gênero de Teresa de Lauretis (1994), com suas próprias especificidades, se aproxima das concepções de Scott e pode contribuir na compreensão de como as representações simbólicas, inscritas no discurso teológico e nas narrativas hegemônicas da modernidade produzem identidades marcadas pelo gênero. Mas que, por outro lado, uma ressignificação dessas representações por sujeitos, até então, considerados "subalternos" permite, também, uma nova produção ou reinvenção de si. Lauretis define a construção do gênero "como o produto e processo tanto de representação quanto da autorrepresentação" (Lauretis, 1994: 217). Ela insiste na necessidade de um conceito de gênero que não esteja tão preso à diferença sexual a ponto de essencializá-la, mas que inclua essa diferença como um efeito da linguagem, contida nas representações sociais. Assim, em Lauretis as representações de gênero são produtos de diferentes tecnologias sociais, tais como: o cinema, os discursos, nos quais se

$8 \quad$ Na década 1990 as discussões em torno do conceito de gênero incorporaram outros aspectos, tais como: posição de sujeito, heteronormatividade e identidades sexuais marginais e corporalidade. Abrem-se, assim, novas possibilidades para a compreensão do corpo, não como uma estrutura fixa dada previamente pela natureza, sobre a qual se constrói culturalmente a distinção de gênero, mas como algo que é materializado pela cultura, conforme as concepções de Judith Butler (2003) 
inserem as teorias epistemológicas e as práticas institucionais, bem como as práticas cotidianas, marginais aos discursos hegemônicos, situadas nas microrrelações políticas. Para a autora, tais tecnologias têm o poder de controlar o campo do significado social e, portanto, de produzir, promover e"implantar", determinada representação de gênero.

Convém lembrar que tornar-se uma pessoa marcada pelo gênero, segundo as teorias contemporâneas do feminismo, não significa identificar-se com uma única feminilidade ou masculinidade, isso porque não existe uma única forma com que as mulheres e os homens individuais possam se identificar em seus contextos sociais, mas sim uma variedade de feminilidades e masculinidades possíveis, fornecidas por representações simbólicas e por discursos concorrentes e contraditórios que existem, e que produzem e são reproduzidos por práticas e instituições sociais (Moore, 2000: 35). Desse modo, mesmo que no discurso teológico alguns termos parecem se remeter a um modelo fixo de feminino e de masculino, consideramos sempre que, dentro de um mesmo contexto, existem "múltiplas feminilidades e masculinidades, múltiplas maneiras de ser feminina ou de ser masculino" (Moore, 2000: 31).

Vinculada a essas posições teóricas, este ensaio de pesquisa busca construir uma espécie de analogia entre o pensamento teológico tradicional e os relatos da modernidade, mostrando como um conhecimento altamente generizado ${ }^{9}$, nesse caso no masculino, construiu representações simbólicas de gênero que produziram efeitos nas subjetividades femininas, bem como na organização social e eclesial. Para isso, optamos percorrer um caminho específico, ou seja, primeiro abordamos algumas questões que colocam em cena a perspectiva masculina do pensamento em diferentes áreas do saber, cuja questão tem sido criticada pela teoria feminista. No segundo ponto, fazemos uma analogia entre o gênero da modernidade e o gênero da teologia católica e, por último, evidenciamos alguns aspectos sobre como foi construída a crítica feminista ao androcentrismo, na literatura modernista e na teologia.

\section{O VIÉS “ANDROCÊNTRICO" DO PENSAMENTO CONTEMPORÂNEO E A CRÍTICA FEMINISTA}

Segundo a literatura feminista, os saberes históricos possuem um viés androcêntrico por serem elaborados unicamente do ponto de vista das subjetividades masculinas e dos valores da cultura patriarcal, produzindo efeitos negativos para a vida concreta das mulheres. Essa característica comumente tem sido denominada de perspectiva androcêntrica do conhecimento. De acordo com Gabriela Castelhanos Llanos (2010), a primeira a usar o termo androcentrismo foi a novelista, poeta e ensaísta estadunidense, Charlote Perkins Gilman (1860-1935). Ela difundiu o termo como a tendência em encontrar o ponto de vista masculino no centro de nossa visão cultural e histórica do

9 Londa Schiebinger (2001) usa essa expressão para se referir a comportamentos, interesses, ou valores culturais tipicamente masculinos ou femininos, cujas características não são concebidas inatas e nem arbitrárias, mas como realidades construídas por circunstâncias históricas que, por isso mesmo, podem mudar por outras circunstâncias históricas. Ao usar esse mesmo termo, estarei me referindo às mesmas questões assinaladas pela autora. 
mundo. Uma definição mais elaborada encontra-se em Macedo e Amaral (2005: 03), em que o androcentrismo é visto como o "sistema de pensamento centrado nos valores e identidades masculinas, em que a 'mulher' é vista como um desvio à norma, tomando como referência o masculino". Levando em conta essa definição, nesse trabalho consideramos o androcentrismo, no sentido de Llanos (2010), como uma prática comum e generalizada, que vai além da linguagem discursiva e que se encontra, também, nas práticas culturais e institucionais.

Considerando essas questões, nesse ponto abordamos alguns aspectos que se remetem a perspectiva masculina do pensamento moderno, que não só perpassa a história, a literatura, a teologia, mas todo o pensamento científico. Ático Chassot (2009) afirma não ser necessário fazer muito esforço para constatar o quanto a ciência é masculina. Essa predominância não é diferente quando se fala da teologia, das humanidades e das artes. Por exemplo, poderíamos nos perguntar quais são as mulheres que se destacam no conjunto dos grandes pintores, escultores? Talvez uma minoria. Isso se repete quando olhamos para outros aspectos da vida social, como é o caso do universo político, no qual o parlamento e outras lideranças políticas continuam sendo, majoritariamente, masculinas. Segundo o autor, a expressão maior se encontra no universo da religião, em que os líderes continuam sendo, em geral, do universo masculino $^{10}$. Dada essa constatação, Chassot (2009: 26) conclui que "não apenas a ciência é predominantemente masculina, mas a própria civilização". Simone de Beauvoir (1949: 193), em outras palavras, já havia mencionado que a "representação do mundo, como o próprio mundo, é operação dos homens; eles o descrevem do ponto de vista que lhes é peculiar e confundem com a verdade absoluta".

Entretanto, para Simone de Beauvoir a civilização não é masculina somente porque predomina a visibilidade do sexo masculino na ciência e nas diferentes instâncias de liderança social, mas, sobretudo, porque as representações culturais e científicas são produtos da experiência masculina. Para essa filósofa, a representação do mundo resulta da complexidade das relações sociais e das formas de representação que estão inseparavelmente vinculadas à posição do sujeito que o representa. Assim, a filosofia, a ciência e a literatura, sendo criações culturais dos homens, acabaram excluindo as mulheres de tal forma que essa exclusão afetou o conteúdo do conhecimento e a própria visão de mundo (Beauvoir, 1949).

Nessa mesma direção, a socióloga Miriam Adelman (2009) recorda que nos campos convencionais da história e da literatura, existe um viés androcêntrico tão forte que exigiu mudanças radicais para que se criasse, dentro deles, qualquer espaço para a voz e as experiências femininas. A autora cita, por exemplo, a literatura, como um dos

10 Neste texto, embora muitas vezes usa-se o termo "masculino" no singular, sabe-se que na estrutura das relações de gênero, do próprio universo masculino, também existem diferentes posições de poder, como já tem mostrado os estudos de masculinidades. Nesse sentido, Robert Connell (1995, p.188) define masculinidades como sendo "uma configuração de prática em torno da posição dos homens na estrutura das relações de gênero", e salienta que existem "mais de uma configuração desse tipo em qualquer ordem de gênero de uma sociedade". Dada esta pluralidade, não deveríamos falar em "masculinidade", mas em "masculinidades". 
campos em que as obras das escritoras ficaram, por muito tempo, "desconhecidas". Isso, também, ocorreu na teologia, pois muitos escritos de espiritualidade e de teologia popular, produzidos por mulheres católicas, quando não proibidos ou queimados, permaneceram "desconhecidos", durante um longo período da história.

Muitos estudos da crítica cultural feminista apontaram o caráter masculino do pensamento ocidental. Entre esses, o de Felski (1995), que versa sobre a história da literatura, o de Adelman (2009) que tem grande acento na teoria social e os de Harding (1996), Chassot (2009) e Graf (2010), que priorizam a ciência. Na teologia também temos muitos estudos, entre esses os de Elisabeth Schüssler Fiorenza (1995), Rosemary R. Ruether (1983), Mary Daly $(1985,1986)$, que influenciaram o pensamento de muitas teólogas brasileiras. No Brasil, a crítica mais expressiva ao pensamento teológico masculino é o de Ivone Gebara (2006a, 2006b, 2008). Essas teólogas chamaram a atenção para as representações simbólicas de gênero inscritas no discurso teológico tradicional, as quais produziram valores e crenças que serviram para normatizar comportamentos, práticas sociais e eclesiais. Nesse sentido, Ivone Gebara menciona que a simbologia dos heróis masculinos não está só no universo religioso, mas em toda a cultura moderna. Essas imagens simbólicas exercem poder, porque projetam mensagens sobre esperanças, sonhos, comportamentos e condutas, produzindo determinados modelos de subjetividades de gênero.

"Vemos obras de artes expostas em praças e nome de avenidas sempre com nome de heróis do sexo masculino. Mesmo com suas contradições e ambiguidades, essas representações simbólicas tem um papel histórico, educativo, simbólico e psicológico importante, isso porque penetra em nosso ser desde muito cedo. Esse processo de educação foi hegemônico no passado e continua até hoje muito forte em muitos de nossos comportamentos, mesmo quejá se tenha conquistado mudanças sociais, devido ao acesso de mulheres aos espaços públicos" (Gebara, 2008: 112. Tradução da autora).

As imagens públicas femininas que, atualmente, servem de exemplo para os cidadãos e cidadãs são poucas e insignificantes, quando comparadas com as masculinas. E, isso acaba construindo um imaginário de que as subjetividades masculinas tem maior reconhecimento político e religioso do que as femininas (Gebara, 2008). Desse modo, o poder dos símbolos culturais, presentes no universo social e religioso, marcaram os processos de socialização, fazendo com que as mulheres acreditassem que eram inferiores aos homens, já que na cultura moderna a música, a literatura, a ciência e a religião aparecem como fundamentalmente masculinas, (Gebara, 2008). Sem dúvida, o caráter masculino do pensamento cultural e religioso trouxe impactos na organização social e eclesial. Serviu, ainda, para ocultar a ação das mulheres e legitimar a sua impotência na produção do pensamento e na condução dos processos históricos.

De acordo com Chassot (2009), se queremos compreender por que a ciência continua majoritariamente masculina, em termos de representação, faz-se necessário buscar as tessituras com outras histórias, como a da filosofia, das artes, da magia e das religiões, já que a ciência está intensamente conectada com a história da humanidade e não pode 
ser lida sem essas diferentes tessituras. Apesar dessa forte marca masculina, sempre existiram mulheres participando e contribuindo na construção do conhecimento, mesmo impedidas de serem membros de comunidades científicas. Elas tinham mais participação e acesso ao conhecimento quando não havia uma separação entre o espaço doméstico e o do fazer ciência. Sua presença foi reduzindo-se quando a casa deixou de ser o lugar do acesso informal da ciência para as mulheres. Com a revolução científica, dos séculos XVII e XVIII, a sua participação na ciência foi limitada. As instituições científicas - universidades, academias e indústrias - foram estruturadas sobre a suposição de que os cientistas seriam homens com esposas em casa para cuidar deles e de suas famílias. Desse modo, com a profissionalização da ciência, no século XVII e XVIII, as mulheres se tornaram assistentes invisíveis de seus maridos (Schienbinger, 2001). Mesmo que reduzida, a participação das mulheres foi importante para a construção da ciência. Entretanto, elas foram invisibilizadas ${ }^{11}$ e colocadas fora da história, tendo que superar barreiras que Ihes foram interpostas. Isso também ocorreu na história recente, pois no início do século XX a ciência e outras carreiras eram, culturalmente, definidas como impróprias para as mulheres e, na segunda metade do século XX, se diziam quais eram as profissões para homens e quais eram para as mulheres.

Evidentemente, sabe-se que o conhecimento é sempre resultado das relações sociais e, especificamente, da maneira como determinadas formas de saber e de conhecer são legitimadas no interior das comunidades epistêmicas. De acordo com Adelman,

"entendemos a ciência como uma forma específica de discursos, de conhecimento institucionalmente organizado e de poder social, que consolida sua legitimidade como parte da revolução burguesa ocidental de sua filosofia iluminista. O fato das mulheres terem estado excluídas dessas comunidades durante muito tempo seria uma parte da história profunda das disciplinas. Parte de um processo duplo de ausência enquanto produtoras de conhecimento (nas instituições onde se produze se transmite o conhecimento científico) e quanto sujeitos (reconhecidos) da história" (Adelman, 2009: 97).

Para Chassot (2009: 46), a perspectiva cultural e política de uma ciência que se produziu masculina, como também todas as formas do pensamento intelectual, está diretamente vinculada à influência que veio do campo religioso, em que a ciência e os demais saberes masculinos foram se fortalecendo a partir de nossa tríplice ancestralidade: grego-judaico-cristã. É nessas nossas origens que encontramos o vínculo religioso, mesmo que se queira contestar que a religião grega não tinha marcas de dominação, não se pode esquecer-se de duas situações: os mitos, que eram tidos como livros sagrados, e a filosofia grega, particularmente o pensamento de Aristóteles,

11 No século XIX houve mulheres que publicaram, por exemplo, os seus trabalhos matemáticos com pseudônimos masculinos, não apenas para merecerem créditos na academia, mas para conseguirem que eles obtivessem um lócus para virem à luz (CHASSOT, 2009, p. 29).

62 / PUNTO GÉNERO 
que se fez sincrético com a escolástica, especificamente, na nascente universidade no mundo ocidental, a partir do século $\mathrm{XI}^{12}$.

Em cada uma das três raízes históricas, as tentativas de leituras revelam a forte influência do pensamento religioso na supremacia do sujeito masculino como o ser racional. Por exemplo, na tradição grega têm-se os mitos ${ }^{13}$ e as concepções biológicas de fecundação de Aristóteles; na judaica, a cosmologia e, particularmente, o mito da criação de Adão e Eva; e na Cristã, somada às explicações oriundas do judaísmo, tem-se a radicalidade das explicações do pensamento de Agostinho, Isidoro, Tomas de Aquino, entre outros ${ }^{14}$ (Chassot, 2009). Essas tradições religiosas naturalizavam a inferioridade das mulheres, imprimindo-Ihes apenas funções vinculadas à natureza biológica, por serem consideradas despossuídas de capacidades intelectuais. Desde os primórdios, os discursos masculinos materializaram práticas sociais desiguais e legitimaram a exclusão das mulheres da ciência, da história e do acesso ao conhecimento. No universo teológico, esse discurso, elaborado segundo a visão e a experiência de um sujeito que é homem e clérigo, produziu um constructo simbólico -discurso, imagens e representações- que naturalizou o feminino como um corpo inferior, passivo e despossuído de intelectualidade.

Apesar da recente inserção da crítica feminista aos discursos androcêntricos e em todos os aspectos da cultura contemporânea, Chassot realça que as marcas da discriminação de gênero continuam muito fortes. No entanto, o debate de gênero na literatura, na sociologia, na história e na linguística possibilitou a crítica ao pensamento androcêntrico e o resgate das contribuições significativas das mulheres nessas áreas, se constituindo uma importante ferramenta para desmascarar o viés masculino do pensamento científico. Adelman nos lembra de que "a revisão do pensamento social ocidental iniciada pelo pensamento feminista ocorreu paralelamente com a emergência da perspectiva pós-estruturalista ${ }^{15}$ e com a teorização sociológica sobre a nova fase da modernidade-sociedade pós-industrial" (Adelman, 2009: 80).

O movimento feminista representou um momento de ruptura radical com a cultura herdada, que foi a da invisibilização das contribuições das mulheres à história, à cultura

12 No artigo Porque a ciência já nasceu machista? Hilton Japiassu, por meio de argumentos fundados em bases históricas, mostra como a ciência estruturou-se a partir de um princípio de racionalidade fundado na filosofia de caráter eminentemente patriarcal-masculino-machista. Detalhes ver Japiassu (2011).

13 Um dos mitos gregos descreve o castigo de Zeus aos homens. Segundo esse mito, Zeus fica irado por ter sido provocado pelos homens e, por isso, cria uma criatura artificial que dá a gênese das mulheres, criaturas que trazem aos homens a avidez do desejo, o fim do contentamento e da autossuficiência. No mito, a primeira mulher se chamava Pandora e, ela trazia consigo uma caixa fechada de onde deixaria escapar todos os males que pesariam sobre os homens.

14 Para aprofundar a influência de cada uma dessas tradições no pensamento científico, consultar Chassot (2009).

15 Como já mencionamos, a linguagem ocupa um lugar central na teoria pós-estruturalista. Ela é vista não apenas como mero veículo de expressão de significados, mas também com poder de construir significados. Dentro dessa compreensão, Michele Barret (1999: 111) situa a importância do conceito de discurso de Foucault, para pensar sobre os significados produzidos pelos regimes discursivos. Assim, a teoria feminista, fundada na perspectiva pós-estruturalista, privilegia os discursos e o universo simbólico para compreender os processos de produção de subjetividades de gênero. 
e à vida política e social. Evidentemente, essa perspectiva foi significativa para a crítica do pensamento cultural-religioso que, como já mencionamos, influenciou a história da ciência e das diferentes áreas do pensamento intelectual.

Segundo Adelman (2009: 85), a primeira teórica a identificar o viés masculinista do pensamento social ocidental foi Simone de Beauvoir. Depois dela, outras gerações de intelectuais feministas e pensadores pós-estruturalistas realizaram diversas formas de revisão do conhecimento produzido por filósofos e cientistas da tradição ocidental. Entre essas intelectuais, Adelman cita Teresa de Lauretis e Maria Rita Khel, cujas feministas realizaram estudos em que desconstruíam o "eterno o feminino", compreendido como produto da subjetividade masculina, que serviram para produzir determinados modelos de mulheres, compatíveis com os projetos e as práticas do imaginário masculino. Vista sob tal perspectiva, "boa parte da produção discursiva moderna é um discurso dos homens sobre o 'grande Outro,' a mulher" (Beauvoir 1949, apud Adelman 2009: 86). Por isso, nos discursos masculinos, as mulheres não aparecem como sujeitos históricos. Além disso, o viés masculino penetrou tudo o que se tornou "conhecimento legítimo" selecionado para o cânone oficial, nas mais diferentes áreas do pensamento acadêmico. Sendo assim, de acordo com Beauvoir (1949), os homens não são capazes de reconhecer a reciprocidade histórica, já que as categorias tidas como absolutas para a compreensão do mundo são construções puramente masculinas.

Para Adelman (2009), a crítica feminista sugere o reconhecimento do poder/saber embutido no conhecimento científico e nas suas pretensões universalistas, conduzindo, para tanto, a uma metodologia de "desconstrução", que parte da proposta de Foucault e que nos permite olhar para os discursos a partir da perspectiva de quem os construiu e, em que condições históricas isso ocorreu. Essa questão nos ajuda a identificar as relações que existem entre as palavras e os poderes. Tal metodologia não deve ser compreendida como uma "tentativa de invalidar o conhecimento já acumulado, mas de avaliá-lo, revisá-lo e, certamente, desta forma, torná-lo mais aberto e mais crítico" (Adelman, 2009: 96).

Nesse sentido, a autora considera que é por meio das experiências femininas, historicamente ocultadas pela cultura androcêntrica, que hoje são construídos outros "canais de acesso", os quais possibilitam novas formas de ser, pensar e agir. Isso vem desvelar a existência de outra história, em grande parte ignorada, mas que aos poucos vem transformando nossa forma de ver a "história oficial".

"Não se trata de avançar em qualquer tipo de posição 'essencialista,' ou seja, de propor mais uma posição binária entre homens e mulheres, masculino e feminino, formas de viver e pensar. Trata-se, sim, de se abrir para aquilo que se apreende pela via da inclusão do antes silenciado, um acréscimo a partir das alteridades. O espaço do feminino, das experiências femininas plurais, pode e deve servir como caminho de acesso às alteridades silenciadas ou marginalizadas, que são constitutivas da nossa experiência social da modernidade, quanto as vozes que foram hegemônicas" (Adelman, 2009: 96). 
Como percebemos, a crítica feminista tem, sim, uma tarefa muito importante, que é a de desmascarar a hegemonia masculina, que caracteriza o pensamento nas diferentes áreas acadêmicas. Isso porque os discursos hegemônicos, além de invisibilizarem a experiência feminina e a sua participação nos processos históricos, reproduziram relações e comportamentos sociais que privilegiaram a ação masculina na história. Nesse sentido, a tarefa da crítica feminista, segundo Adelman, envolve três grandes ações:

\begin{abstract}
"a) a desconstrução do discurso masculinista sobre a 'Mulher'; b) a desconstrução do discurso sobre o 'homem' universal, demonstrando como ele foi elaborado a partir do referencial da experiência de uma categoria particular de homens; c) o ato de repensar a sociedade também a partir das experiências das mulheres (e, portanto, igualmente dos homens, mas não mais como 'norma' universal) em toda a sua historicidade e especificidade, isto é, a partir das relações de poder entre os gêneros e sua interseção com outras relações sociais, particularmente as de classe, raçal etnicidade e orientação sexual" (Adelman, 2009: 95)
\end{abstract}

Essa mesma tarefa foi assumida pela Teologia Feminista, a qual emergiu como uma "outra voz" no universo do pensamento teológico. Um saber elaborado pelas mulheres, pautado, sobretudo, na tradição dos estudos feministas dos anos de 1970 e pela incorporação da categoria analítica de gênero. Trata-se de uma teologia "alternativa"em relação a que fora produzida pelo sujeito masculino porque, pautada nas experiências encarnadas das mulheres, produziu uma crítica aos significados de gênero inscritos na teologia católica tradicional, ressignificou as imagens simbólicas do feminino e visibilizou a contribuição histórica das mulheres na construção do cristianismo. Assim como em outros campos do saber, na teologia a contribuição das mulheres havia sido historicamente ocultada e, quando mencionada, era narrada a partir do olhar da subjetividade masculina.

\title{
2. UMA ANALOGIA ENTRE O GÊNERO DA MODERNIDADE E GÊNERO DA TEOLOGIA CATÓLICA
}

A feminista Inglesa Rita Felski ${ }^{16}$ (1995) faz uso da metáfora de gênero para descrever a modernidade ${ }^{17}$. Para ela, este tempo histórico é altamente generizado, uma vez que os personagens e os símbolos presentes nos relatos da modernidade são precisamente masculinos. Por isso, mais do que fazer uma crítica entre a modernidade e a pós-modernidade a autora levanta questões que possibilitam evidenciar as cegueiras em relação às questões de gênero na literatura e na história. Ela assume a perspectiva da crítica feminista, mostrando que tanto a teoria moderna como a pós-moderna, em geral, têm sido produzidas ou organizadas em torno da norma masculina, desconsiderando, com isso, as experiências das mulheres.

16 Rita Felski é uma estudiosa na área da teoria literária, teoria feminista, da modernidade, pós-modernidade e estudos culturais.

17 Como já mencionamos, Felski (1995) pensa a modernidade como um período histórico, com uma filosofia de vida, diferente da época anterior, justamente por descartar a crença da onipresença da autoridade divina e centrar-se sobre a individualidade, a subjetividade e a autoconsciência. Ela inclui, nessa concepção, os processos de modernização e o próprio modernismo, que são por ela identificados de forma distinta. 
Sob a inspiração que emerge do pensamento de Felski, neste ponto procuramos lançar um olhar sobre a teologia católica tradicional, enquanto sistematização de um saber fundado na experiência de fé. Surge a seguinte questão: se o pensamento teológico, assim como os relatos da modernidade, foi, ao longo da história, organizado e produzido segundo uma norma social masculina, não se poderia afirmar que este pensamento também é generizado? Partimos dessa problematização para construir uma analogia entre o "gênero" da modernidade' e o "gênero" da teologia.

Felski analisa a literatura histórica da modernidade e afirma que os sujeitos humanos individuais ou coletivos, que aparecem investidos de importância simbólica, acabam por sintetizar os principais significados dessa época. Desse modo, quando esses sujeitos são presumidamente masculinos ou femininos apresentam, também, consequências significativas para o tipo de narrativa desenvolvida. Isso porque, "o gênero não apenas afeta o conteúdo real de nosso conhecimento histórico - o que é relatado e o que é ignorado-, mas também a concepção filosófica implícita em nossas interpretações da natureza e do processo social" (Felski, 1995: 01).

Essa concepção de Felski nos permite considerar que, também, o pensamento teológico historicamente produzido por homens celibatários, brancos e heterossexuais, foi imprimindo significados e hierarquias sexuais no espaço socioeclesial. Em outras palavras, o caráter masculino do pensamento trouxe impactos na organização eclesial por invisibilizar a ação das mulheres e legitimar a sua impotência na produção do pensamento e na condução dos processos histórico-eclesiais. O homem clérigo foi quem assumiu o papel de sujeito coletivo da história eclesial, enquanto as mulheres eram consideradas como o "outro", ou seja, como objeto e não como sujeito da narrativa teológica. Assim sendo, o discurso teológico, elaborado segundo a visão e as experiências do sujeito masculino e clérigo, fundado no nível do sagrado e do simbólico ${ }^{18}$, produziu determinadas representações de gênero, que justificaram a exclusão das mulheres nas instâncias de poder eclesial, legitimando, assim, o androcentrismo na produção do pensamento teológico. Isso até o século XX, sobretudo, a partir da década de 1970, quando finalmente as mulheres começaram a ingressar nos cursos de formação teológica ${ }^{19}$, ainda que de forma pouco expressiva, e mais tarde, nos anos de 1980, se inseriram, também, no campo do ensino e da produção acadêmica.

Na concepção de Felski (1995), mais do que submeter a história das relações de gênero às grandes metanarrativas, articuladas sob o ponto de vista do presente, o importante para as feministas era compreender como as mulheres e os homens do passado entendiam a sua posição dentro dos processos histórico-sociais. Esse entendimento, evidentemente, não só recebe a influência dos relatos da modernidade, que

18 O sentido simbólico desse discurso vem revestido por uma forma masculina de interpretação dos textos bíblicos, em que se enalteceram algumas características das figuras femininas da histórica bíblica e se ocultaram outras, segundo os interesses da cultura patriarcal.

19 A entrada das mulheres nesses cursos acadêmicos coincide, justamente, com o período de transformações socioculturais, em que as mulheres, em geral, começaram a ter acesso, em maior número, ao ensino superior e, consequentemente, foram assumindo a docência nas universidades, em diferentes áreas do saber acadêmico. 
protagonizaram as personagens masculinas, mas também dos discursos religiosos que, influenciados pelo dualismo grego e pela moral judaico-cristã, continuam influenciado a vida das mulheres, para além do espaço eclesial. Daí a importância de verificar as representações de gênero presentes no discurso teológico católico tradicional e como essas representações produziram significados culturais, subjetividades e práticas socioeclesiais. Por outro lado, apesar da hegemonia masculina na produção do saber teológico, uma investigação mais detalhada aponta a existência de vozes femininas que elaboraram discursos teológicos paralelos, sobretudo na área da espiritualidade, como é o caso de Tereza de Ávila e de Catarina de Siena ${ }^{20}$. No entanto, os discursos femininos não foram incluídos no cânone da teologia católica oficial. Isso só vem ocorrendo na história recente, quando se começou a colocar em pauta a questão das mulheres na história do cristianismo. Essa mesma realidade também ocorreu em outras áreas do saber, como menciona Felski, uma vez que "a visão natural essencialmente masculina deixou os escritos das mulheres fora da história ignorando a sua ação em diferentes aspectos do desenvolvimento social" (Felski, 1995: 17; tradução da autora).

Nos últimos trinta anos, as vozes que, até então, eram consideradas "subalternas", ecoaram na área do saber teológico, ressignificando e recriando saberes, tomando como critério a experiência das mulheres e as perspectivas epistemológicas da feminista e dos estudos de gênero. Assim como ocorreu no universo dos estudos culturais e literários, as teólogas feministas também construíram críticas às teologias ${ }^{21}$ androcêntricas desnaturalizando os significados das representações simbólicas de gênero inscritas nesses discursos. A corrente feminista da teologia criticou o pensamento teológico tradicional por privilegiar a experiência do sagrado vinculada às figuras bíblicas masculinas, ocultando ou colocando em segundo plano as figuras femininas, como se fossem seres inferiores. Essa percepção levou as teólogas feministas a fazerem uma releitura da história bíblica, com o objetivo de resgatar as heroínas femininas, que se destacaram por sua liderança e de enfatizar as virtudes da figura de Maria, que não tiveram expressão no pensamento androcêntrico. Elas passam a reler os textos bíblicos com o objetivo de desconstruir os signos que prendiam as mulheres à uma imagem negativa, que havia sido produzida pela tradição cristã, marcada pelo peso do pecado original (Rodhen, 1997). Nota-se, que a preocupação das teólogas feministas, na busca de uma releitura e ressignificação de conceitos e imagens inscritas no saber teológico, assume a característica de uma das tendências iniciais do feminismo que se debruçou sobre os estudos da história das mulheres.

20 Tereza de Ávila viveu no século XIV e foi considerada uma das maiores mestras da espiritualidade católica, deixando obras de grande valor. Pelo valor teórico de seus escritos e, junto com Catarina de Siena, muito recentemente, em 1970, foi declarada doutora da Igreja, pelo Papa Paulo VI. Catarina viveu no século XII (1347-1380), mas o valor de seu trabalho e a sua atividade eclesial só foi reconhecida no final do século XX. Ela era analfabeta, mas ditou mais de 300 cartas endereçadas à diferentes categorias de pessoas - papas, reis, líderes e ao povo humilde. Lutava pela unificação da Igreja e a pacificação dos Estados Papais. Uma das suas obras ditadas, Diálogo sobre a Divina Providência é, ainda hoje, considerada um dos maiores testemunhos do misticismo cristão e uma exposição clara de suas ideias teológicas e espirituais.

21 Apesar de nos focarmos na teologia de confissão católica, convém lembrar que esse processo ocorreu, simultaneamente, nas diferentes teologias cristãs (protestante, metodista, entre outras). 
Segundo Felski (1995), no campo social da teoria política as representações masculinas trouxeram maior impacto, isso porque as estruturas institucionais governadas por homens lideravam quase todas as questões da vida e das preocupações das mulheres. De modo que o pensamento masculino não era somente algo abstrato, mas operava politicamente trazendo consequências materiais e concretas na vida dos sujeitos femininos. Essa mesma realidade se observa na esfera eclesial, onde o discurso teológico católico tradicional legitimou a hierarquia masculina celibatária como a representante da divindade, com plenos poderes para orientar os comportamentos morais dos cristãos/ãs. Nesse sentido, as maiores prejudicadas na história do cristianismo foram as mulheres, já que o discurso teológico, considerado um discurso de verdade, fundando na revelação divina ${ }^{22}$, legitimou a exclusão das mulheres dos espaços de liderança eclesial e a sua submissão à ordem social masculina.

Felski (1995: 16) afirma que a modernidade identificada com a "masculinidade" não é uma invenção, mas uma questão legitimada e produzida teoricamente. Ela fundamenta essa posição mencionando que os símbolos da esfera pública, considerados figuras representativas da modernidade no século XIX, como o estrangeiro, o dandi, o flaneur, são figuras explicitamente generizadas no masculino. Segundo essa autora, se ao invés da figura masculina, tivéssemos uma mulher andando no meio da multidão, ela não teria o mesmo status do homem, mas seria considerada uma prostituta. De igual maneira, no universo do pensamento teológico católico, por muito tempo, se reforçou os atributos masculinos da imagem de Deus, como o Senhor dos senhores, o Juiz dos juízes, o Rei dos reis, o Deus forte, o Todo-poderoso, cuja vontade deveria ser obedecida. Essas imagens da divindade justificaram as estruturas patriarcais na família, na sociedade e na Igreja, tornando as hierarquias "normais" e abençoadas por Deus. $O$ discurso teológico, além de acentuar a imagem masculina da divindade, institucionalizou e universalizou o sujeito masculino nos processos de produção do saber e, enalteceu, ainda, as grandes figuras masculinas da história do pensamento teológico ou da liderança eclesial. Dentro da lógica de que a racionalidade era uma "essência" masculina, as mulheres foram afastadas da atividade intelectual e impedidas de ocuparem lugares significativos na liderança eclesial e social. Contudo, sempre houve vozes resistentes que se destacavam pela divulgação de saberes cotidianos, relacionados à culinária, às práticas medicinais, à literatura e que se opunham a ordem do "saber legítimo". No contexto medieval, as mulheres que se projetavam pela sua intelectualidade e capacidade de liderança e que ousavam pensar de forma diferente do conhecimento instituído no cânone eclesial da ordem simbólica masculina eram consideradas bruxas ou feiticeiras ${ }^{23}$, condenadas à fogueira pela inquisição ${ }^{24}$, silenciadas, reprimidas ou

22 No cristianismo, acredita-se que Deus se revela aos seres humanos por meio da Sagrada Escritura e por meio dos acontecimentos históricos, lidos a partir de uma perspectiva de fé

23 Sobre o conhecimento produzido pelas "bruxas" e feiticeiras e a sua perseguição, a partir de uma leitura em perspectiva de gênero, consultar GRAF, 2011.

24 Entre as mulheres queimadas vivas pela inquisição encontramos Joana d'Arc. De origem francesa, ela é considerada uma das mulheres mais fortes e guerreiras que o mundo já conheceu. Por causa de suas visões foi acusada de praticar feitiçaria, sendo condenada pela inquisição à morte na fogueira. Depois de quase 500 anos de sua morte, em maio de 1920, o papa Bento XV reconheceu as boas intenções de Joana d'Arc e a canonizou como Santa Joana d'Arc.

68 / PUNTO GÉNERO 
colocadas no "seu lugar", ou melhor, no lugar que os homens designavam para as mulheres. Na teologia, o controle masculino sobre o pensamento feminino continuou também no contexto da modernidade. Nesse sentido, uma das vozes resistentes silenciada na América Latina foi a da religiosa católica, poetisa e literata, Sóror Juana de la Cruz $^{25}$, que viveu no século XVII. Ela foi uma grande defensora das mulheres e, num tempo em que elas não estudavam, propôs corajosamente que se criassem escolas para as mulheres, argumentando que "nem a tolice é exclusiva das mulheres e nem a inteligência é privilégio dos homens". Por sua luta, em favor da capacidade intelectual das mulheres e do direito destas se educarem em todas as áreas de saber, ela foi considerada uma precursora do feminismo (PAZ, 1998) ${ }^{26}$. Sua fama intelectual ganhava espaço junto às altas personalidades de seu tempo. Sua perseguição começou quando, numa rara incursão pela teologia, escreveu uma carta criticando o sermão de Padre Antônio Vieira e, como na época teologia e política andavam juntas, ao atacar o padre atacou também um dos grandes políticos. Um de seus perseguidores foi seu próprio confessor, o jesuíta Nuñes de Miranda, que a recriminava por escrever, uma vez que ele acreditava que esta era uma atividade puramente masculina. Soror Juana foi obrigada a dedicar-se à religião na vida de penitência, desfazendo-se de sua biblioteca. Ou seja, ela foi obrigada a silenciar e a negar seu potencial intelectual, para assumir uma posição de invisibilidade ou o lugar que a hierarquia da Igreja legitimava como sendo feminino.

A identificação da modernidade com o espaço público e com a legitimidade da autoridade patriarcal, de acordo com Felski, fez com que se acreditasse que as mulheres estavam fora dos processos históricos de mudança social. Sem dúvida, a teologia católica reforçou essa mesma dinâmica social, uma vez que, ao longo da história, enalteceu a superioridade dos homens em relação às mulheres, afirmando a dignidade masculina e negando às mulheres o direito de ser plenamente "imagem de Deus". Essa construção teológica recebeu fortes influências da filosofia grega, sobretudo, a de Aristóteles, em cujo pensamento as representações simbólicas colocavam as mulheres numa posição de inferioridade, que era justificada por sua condição biológica. Essas ideias influenciaram o pensamento filosófico e teológico de Agostinho ${ }^{27}$ e de Tomás de Aquino ${ }^{28}$, os quais se tornaram os grandes inspiradores da teologia na Idade Média e Moderna. Um pequeno recorte do pensamento de Santo Tomás de Aquino assim expressa:

25 Segundo Octavio Paz (1998), Sóror Juana Inêz de la Cruz amava os livros e era uma autodidata. Pensou até em vestir-se de homem para frequentar a universidade, cujo privilégio na sua época era somente para os homens. Acabou indo para um convento, pois no contexto de seu tempo, só como freira poderia realizar o seu projeto intelectual.

26 Isso porque ela adiantou em 200 anos ideias sobre a igualdade entre homens e mulheres e as lutas que depois foram protagonizadas pelo movimento e pelas teorias feministas. Para muitas feministas, ela é considerada a patrona das feministas da América Latina (GEBARA, 2004).

27 Agostinho (354-430 d.C.) foi um bispo cristão, considerado o mais profundo filósofo da era patrística e, um dos maiores gênios teológicos de todos os tempos.

28 Tomás de Aquino (1225-1274) foi um dos grandes teólogos e filósofos da historia da Igreja. O corpo teológico formulado pelos seus escritos veio a ser chamado Tomismo, que é a coroação da Escolástica. O seu mais importante trabalho foi a obra chamada Suma Teológica. 
"A igualdade entre os dois sexos existe no plano da graça e da salvação, mas não no plano da natureza, pois a virtude ativa que se encontra na semente do macho visa produzir algo que se assemelhe em perfeição ao sexo masculino. Se por acaso uma mulher for gerada, é em função da fraqueza dessa virtude ativa ou de alguma má disposição da matéria, ou até de alguma transmutação vinda do exterior. [...] O sexo feminino não pode significar superioridade em nada, porque o estado da mulher é sujeição. Ela não pode, portanto, receber o sacramento da ordem" (Aquino, Suma Teológica v.2, 1980: 92)

Como se observa nesse pequeno relato, o pensamento teológico masculino, ao reproduzir um discurso que justificava a inferioridade das mulheres como se elas estivessem vinculadas à uma suposta "natureza biológica", contribuiu com reprodução da cultura patriarcal, tanto em âmbito social como no espaço eclesial. Desse modo, a teologia tradicional católica legitimou a naturalização do espaço privado para as mulheres, como uma "determinação divina", pela crença em uma suposta inferioridade inscrita em sua própria "natureza". Assim, caberia às mulheres somente as funções de mãe e esposa, numa relação de subordinação ao homem.

Para Felski, o modelo de uma oposição binária entre os sexos, que era socialmente percebido em esferas separadas, subscreveu todo um sistema de práticas institucionais e convenções, nos meados do século XIX, que vão desde uma divisão sexual do trabalho até uma divisão sexual dos direitos econômicos e políticos. De forma semelhante, essa concepção binária esteve presente no pensamento teológico e serviu para reproduzir e ligitimar a divisão sexual do trabalho, não somente no espaço social, mas também no eclesial, como já descrevemos acima.

Por outro lado, essa visão fechada e dicotômica do século XIX, que reforçava a divisão entre público/privado, masculino/feminino, moderno/antimoderno, segundo Felski, não se definou como algo fixo, mas somente como aparência. Ou melhor, elas foram desfeitas e refeitas em novas modalidades. A mudança deste estatuto foi possível, também, com as condições de urbanização e de industrialização, que se manifestou mais como uma ligação metafórica das mulheres com a tecnologia e a produção em massa. As mulheres deixam de ser colocadas em oposição à simples lógica da racionalização do moderno e passam a ser construídas por essa mesma lógica. Assim, segundo Felski (1995), certas figuras femininas públicas como a imagem da mulher máquina ou trabalhadora das fábricas, da atriz e da lésbica, evocadas nos trabalhos de escritores masculinos franceses, no século XX, passaram a apresentar algumas das ambiguidades do capitalismo. No entanto, a crítica da autora é de que as representações das feminilidades, vigentes no pensamento androcêntrico, foram moldadas segundo os interesses e fantasias masculinas e, por isso, não podem ser lidas como representações precisas das experiências femininas. De igual maneira, no discurso teológico masculino, as representações sobre as mulheres ou mesmo a seletividade dos atributos enaltecidos nas figuras bíblicas femininas, nem sempre representaram a experiência concreta das mulheres, ou os seus reais atributos, mas serviram para produzir um determinado modelo de subjetividade feminina, que respondia aos interesses da manutenção e da reprodução de uma cultura fundada no sistema do 
patriarcado ou, nos termos da teóloga feminista Elisabeth Schüssler Fiorenza (2009), no sistema kyriarquico ${ }^{29}$.

A partir de seus argumentos, Felski afirma que o gênero da modernidade é masculino não só porque o sujeito do pensamento foi majoritariamente masculino, mas também pelas representações que este pensamento produziu, orientando comportamentos e formas de organização social. Por esses mesmos argumentos, podemos considerar que o gênero da teologia é, igualmente, masculino, justamente porque as representações simbólicas desse pensamento não só produziram, mas normatizaram os comportamentos e os papeis para sujeitos femininos e masculinos, dentro das estruturas sociais e eclesiais.

No seu estudo, Rita Felski refuta a feminilidade já dada pelo pensamento masculino, propondo-se a explorar algumas das diferentes formas em que as mulheres se basearam para contestar ou reformular as representações dominantes de gênero na modernidade. Sua visão é de que não existe uma história das mulheres fora das estruturas vigentes da modernidade. É neste contexto que as mulheres experiementaram as mudanças de gênero, de forma específica, mesmo que fraturadas, não só pelas hierarquias de classe, raça e sexualidade, mas pelas diferentes identidades sobrepostas que assumiam em suas práticas como mãe, leitoras, trabalhadoras, artistas, amantes e, assim por diante. É nessa perspectiva que, segundo a autora, há um encontro distintamente feminino com as diferentes facetas do moderno, que foi largamente ignorado pelas grandes teorias sociais e culturais, no engendramento dos processos sociais.

No universo teológico, as feministas também fizeram uma releitura do discurso hegemônico, críticando as formas como o "feminino" foi representado na teologia tradicional, cujo discurso, praticamente, excluiu e invisibilizou a atuação concreta das mulheres na história do cristianismo, se caracterizando por uma visão típica do desejo "masculino" (Brancher, 2009). Por exemplo, as virtudes de Maria destacadas na Mariologia ${ }^{30}$ masculina e nos quantros Evangelhos ${ }^{31}$ são a de uma Maria jovem pura, ingênua na sexualidade, serva obediente, submissa, a mãe afilta com o filho, a Maria do silêncio, que suporta o sofrimento sem reclamar. Esse modelo de mulher, segundo Mercedes Brancher (2009), atende aos desejos sonhados pelo kyriarcado. Nesse sentido, para a teóloga feminista Elisabeth Schüssler Fiorenza (2000: 231) "a supremacia do mascunino no controle da mariologia cria uma imagem sociocultural do feminino

29 O termo kyriarquia foi criado pela teóloga feminista Elisabeth Schüssler Fiorenza, cuja expressão vem da palavra grega kýrios que significa "dono", "senhor de escravos", "pai de família" e da palavra archein que se remete ao termo "dominar ou governar". Assim, para Fiorenza (2009: 28) kyriarquia é um "sistema sociopolítico de dominação, no qual uma elite de homens educados e de posse mantém o poder sobre mulheres e outros homens. kyriarquia é teorizado melhor como um sistema complexo e piramidal de estruturas sociais multiplicativas que se cruzam de supremacia e subordinação, de domínio e opressão". Para essa teóloga, o patriarcado ocidental é ainda um kyriarcado, já que, em geral , os que assum o poder e continuam articulando a exploração das mulheres são um grupo de homens, brancos, proprietários e pertencente a uma elite.

30 Refere-se ao conjunto de estudos teológicos da Igreja Católica sobre Maria, a mãe de Jesus, que compreende uma vasta produção bibliográfica e que visa salientar a figura feminina de Maria e a relação de fé dos fiéis para com ela.

31 São livros os bíblicos de Mateus, Marcos, Lucas e João que relatam a vida e missão de Jesus. 
que santifica a marginalização e a exploração das mulheres". Essa imagem de Maria, segundo a autora, não é um modelo que inspirava e libertava as mulheres da domininção masculina. As teólogas feministas deram acento à outros atributos da imagem de Maria, tais como: a) Maria Mãe-Deusa, que assemelhava Maria às antigas deusas mitológicas da Grécia e reforçava a divindade de Maria; b) Maria Apóstola, que acenava para a liderança exercida por Maria e pelas outras mulheres no movimento de Jesus ${ }^{32}$. As teólogas resgataram, ainda, dos relatos bíblicos as imagens femininas da divindade, como a da Divina Ruah, Sofia, Deus Trindade, Deus Mãe, entre outras, que possibilitavam construir uma imagem positiva das mulheres, como forma de resistência à concepção negativa, produzida pela teologia androcêntrica. Isso mostra concretamente como, ao desconstruir e ressignificar os modelos de gênero, produzidos de acordo com a visão masculina, as teólogas se aproximavam com as correntes do feminismo da diferença dos anos de 1970, que valorizavam a singularidade do feminino na luta pela igualdade, cuja perspectiva tem sido criticada por sua tendência essencializadora (Rodhen, 1997). No universo teológico, essa postura não parece provocar rupturas, mas antes se apresenta como uma estratégia política, cujo interesse é dar legitimidade a presença das mulheres em um lugar que, até então, era proibido para elas.

\section{A LITERATURA MODERNISTA E A TEOLOGIA MASCULINA: CRÍTICA E PRODUÇÃO DE NOVAS NARRATIVAS}

A analogia entre discurso da teologia católica e os relatos literários da modernidade que construímos, em relação às representações de gênero, apontam que ambos os discursos são claramente generizados. Isso não só no fato de a literatura ser uma construção masculina, mas, sobretudo, porque as representações simbólicas do pensamento foram produzidas de acordo com os interesses de uma ordem social androcêntrica que precisava ser mantida.Nessa seção nos focaremos, especificamente, em alguns pontos da crítica feminista à literatura modernista e à teologia androcêntrica, mesmo que ela já tenha aparecido no corpo deste artigo, para mostrar como a crítica do feminismo foi penetrando todas as áreas do conhecimento, que vai desde as ciências até as humanidades.

Rita Felski, a autora que selecionamos para fazer esse contraponto com a teologia, priorizou sua crítica dando maior atenção à literatura e à arte modernista. Constatou que as tradições modernistas anglo-americana e europeia estão unidas pela reprodução, em grande parte, acrítica de uma cultura masculina, ou mesmo por adotar

32 Segundo Hoornaert, (1991:51-53) o movimento de Jesus está ligado à sua ação e a do grupo dos seus seguidores. Essa ação precisa ser compreendida dentro da tradição dos movimentos populares da sociedade judaica dos anos 30 d.C. Esse autor distingue o movimento de Jesus a partir de quatro características: a) um movimento que se alicerça em favor dos empobrecidos e contra a dominação política econômica e religiosa que excluía os pobres da vida social; b) um movimento baseado na tradição bíblica, uma vez que sua atividade se inicia por meio da participação das sinagogas, em fidelidade a Aliança de Deus com seu povo e à tradição dos primeiros patriarcas; c) um movimento de caráter rural, isso porque Jesus desenvolveu sua atividade com o povo do campo, como da pequena Galileia e não tanto nas cidades; d) um movimento juvenil, pois ele mesmo era jovem (30 anos) e seus discípulos e discípulas o que tudo indica também eram jovens. Nesse movimento, as mulheres tinham protagonismo, embora tenha sido pouco destacado por escritores bíblicos. 
uma perspectiva de linguagem literária machista, baseado na exclusão de tudo o que está associado ao feminino. Já, na teologia, no que se refere à interpretação bíblica, quando se ressaltou o "feminino" foi quase sempre numa perspectiva que privilegiou a supremacia do "masculino" e legitimou uma posição subalterna para as mulheres. Desse modo, as téologas feministas, ao emergirem como sujeito de saber teológico, estabeleceram uma forte crítica ao pensamento androcêntrico, "suspeitando" do já dito. Por esse motivo, elas se mobilizaram e se articularam na elaboração de uma outra leitura da teologia tradicional, interpretando a Bíblia a partir de suas experiências como mulheres de fé, situadas no codiano do mundo vivido e afirmando-se como atoras e sujeitos de reflexão, como se verifica no fragmento de uma teóloga feminista brasileira:

"A mulher vai descobrindo uma nova maneira de fazer teologia, a partir da tomada de consciência da fecundidade libertadora de uma releitura bíblica, e da necessidade de descobrir a sua própria identidade, 'desconhecendo o lugar' que o homem the outorgou e que foi por ela introjetado" (Tepedino, 1985: 376).

Na visão de Ana Tepedino, foi por meio da produção teológica, feita pela perspectiva das mulheres, que elas se lançaram no desafio de "desconhecer o seu lugar", ou seja, "desconhecer" o lugar que Ihes fora outorgado pela perspectiva androcêntrica e que elas mesmas haviam internalizado. Ou seja, elas eram cúmplices do próprio poder que as submeteram, de modo que o uso do termo "desconhecer", também justificava a nova realidade experimentada pelas mulheres, uma vez que, até então, ocupavam na sociedade e na lgreja um lugar subalterno e passivo. Esse momento também marca o início de um processo de resistência e reinvenção da subjetividade feminina, que parece se autoafirmar por meio da contragenealogia, ou de um produzir-se de novo. A revisão crítica da teologia católica tradicional visava questionar e desconstruir as noções de gênero, inscritas no discurso teológico masculino, que produziam efeitos negativos na vida das mulheres. O resgate e a visibilidade de personagens femininas da história bíblica e de outros atributos de Maria, não mencionados pelo pensamento masculino, como já o descrevemos, são parte da crítica feminista que trouxe um caráter inovador ao campo da produção acadêmica teológica.

De modo semelhante, porém específico, isso também ocorreu no pensamento modernista. Em sua obra, Felski (1995) faz a menção à algumas feministas que elaboraram uma releitura crítica da literatura modernista masculina, evidenciado que a arte moderna foi sendo apropriada pelo projeto feminista, por meio de uma inquietação ante a tradicional fixidez da hierarquia de gênero. Nesse sentido, além de produzirem leituras revisionistas do cânone modernista do sexo masculino, a crítica feminista também trouxe à tona as mulheres que foram teóricas importantes do modernismo. Assim, pela releitura de escritoras como Virginia Woolf e Gerturde Stein, elas começaram a recuperar a tradição das teóricas modernistas, que não eram conhecidas e, portanto, buscaram remodelar e redefinir os contornos da história literária. Para Felski, há claras razões institucionais para tais intervenções, já que elas visavam trazer mais mulheres para os cânones literários existentes, chamando a atenção para o carácter inovador e formalmente sofisticado de sua arte. "A crítica feminista da história literária é melhor alcançada não por negar a existência de diferenças formais e estéticas entre os textos, mas 
sim por questionar e repensar os significados que são freqüentemente atribuídos a essas distinções" (Felski, 1995: 24. Traduação da autora).

No universo do pensamento teológico, uma leitura crítica do cristianismo, que se tornou referência para a elaboração da Teologia Feminista brasileira, se encontra na obra de duas téologas feministas internacionais, Elisabeth Schüssler Fiorenza e Rosemary R. Ruether ${ }^{33}$. Essas autoras revisaram a história sobre a origem do cristianismo, mostrando que no seu início havia uma estrutura de participação igualitária, em que as mulheres eram incluídas nos processos de evangelização e na liderança, dentro das comunidades primitivas. Entretanto, os discursos masculinos, aos poucos, foram eliminando da tradição cristã os elementos que asseguravam uma participação ativa e igualitária entre homens e mulheres. Isto é, se eliminou escritos que relatavam a proeminência das mulheres na relação com Jesus, bem como a sua liderança no início da evangelização apostólica. Assim, o "homem" foi se tornando o normativo. Com isso, a ação das mulheres no cristianismo foi sendo invisibilizada e se distorceram as relações dialéticas, como bem/mal, alma/corpo, polarizando, desse modo, o masculino/positivo versus o feminino/negativo (Rohden, 1995). Ao suprimir qualquer referência da liderança das mulheres no Movimento de Jesus, aos poucos, os Padres da Igreja ${ }^{34}$ foram legitimando a ordem social do patriarcado, que colocava os homens em uma posição de superioridade e as mulheres na posição de submissão. Pela leitura revisionista dos escritos sobre os primórdios do cristianismo, as teólogas feministas buscaram resgatar a história em vista da valorização da ação das mulheres, questionando, ao mesmo tempo, as bases da lgreja patriarcal e a ordem "sexista", presente na estrutura da Igreja contemporânea.

Evidentemente, tanto no pensamento literário modernista quanto na teologia católica se inauguram novas bases epistemológicas do conhecimento, nas quais os sujeitos "subalternos" transgridem fronteiras linguísticas e acadêmicas, fazendo-se ouvir. Nesse sentido, segundo Rita Felski, "as alegações epistemológicas para a verdade da escrita modernista aponta à necessidade de algumas modificações, isso é, pode ser traduzido como um ato politico" (Felski, 1995: 28. Tradução da autora). Na mesma perspectiva, a teóloga Delir Brunelli (2000), ao mencionar a importância epistemológica da perspectiva feminista na teologia, considera que a abordagem analítica de gênero permite questionar as estruturas do pensamento teológico, já que esta abordagem, além de se constituir em uma mediação hermenêutica, é também uma mediação epistemológica.

"A análise de gênero está permitindo compreender melhor e aprofundar o caráter androcêntrico e patriarcal da teologia, já percebido na segunda fase da produção teológica das mulheres. Com essa mediação se desmascara a pretensão do universalismo' de um discurso no qual o masculino é o normativo e se faz também uma

\footnotetext{
33 Essas obras, respectivamente se intitulam: As origens cristãs a partir da mulher e Sexismo e religião.

34 Os "Padres da Igreja" são considerados como os "grandes homens da Igreja" do século Il ao século VII, os quais foram como que "Pais" da Igreja, porque elaboraram os conceitos da fé cristã e, de certa forma, foram os responsáveis pelo que se denomina de Tradição da Igreja.
} 
crítica radical ao patriarcalismo presente em todo o sistema de relações sociais" (BRUNELLI, 2000: 215).

Nessa mesma direção, Felski (1995) considera que o surgimento da categoria de gênero marca um novo momento na forma de teorizar o social e se constitui um instrumento para entender a dupla questão da generização da história e da historicidade de gênero. Em outras palavras, a emergência da categoria de gênero na produção do conhecimento nos possibilita compreender como a história, as ciências, as narrativas da modernidade, bem como as narrativas do próprio cristianismo são altamente generizadas e, por outro lado, como tais narrativas, no decorrer da própria história, produziram as relações sociais de gênero, segundo os padrões da cultura patriarcal.

Na área do pensamento modernista, escritoras como a poeta feminista Geltrude Stein são frequentemente mencionadas para chamar atenção à crítica feminista, sobretudo, pela sua rebeldia às convenções linguísticas e sociais e ao seu transgressor questionamento às representações de feminilidade, dadas pelo pensamento dominante. Na área da teologia católica e brasileira, uma das grandes transgressoras das conveções colocadas pelo pensamento masculino, do meu ponto de vista, é a filósofa e teóloga Ivone Gebara ${ }^{35}$, a qual foi imposta ao silêncio pelo Vaticano em 1989, por causa de suas ideias, consideradas contrárias à "doutrina oficial" da Igreja.

Convém mencionar que um dos aspectos centrais dos estudos feministas, tanto na literatura como na teologia, tem sido a preocupação com o cotidiano e com as experiênicas situadas das mulheres e a consequente recuperação dessas dimensões como estratégia política de afirmação positiva do feminino e como base metodológica para os processos de produção do conhecimento. Tal perspectiva, muitas vezes, tem sido julgada como insignificante do ponto de vista do pensamento universal,abstrato e masculino.

Felski insiste em dizer que a compreensão ampliada do texto cultural pode contribuir significamente no processo de reteorizar o moderno, quebrando as distinções tradicionais entre um radical vanguardismo, frenquetemente, codificado como masculino e uma cultura de massa, em geral, descrita como o regressivo, o sentimental e o feminino. Em particular, os trabalhos feministas recentes, na área da cultura popular e dos estudos culturais, segundo Rita Felski, vem construindo um caminho para se repensar a modernidade e as mulheres, incluindo uma dimensão política da arte experimental, que pode ir além de uma ficção do real, isolada num texto. Se no campo da arte e da literatura há uma preocupação, por parte das feministas, em reteorizar o moderno e as mulheres rompendo com as distinções de gênero, na teologia essa mesma preocupação é constante. A produção de teológas feministas tem se proposto

35 A teóloga Ivone Gebara é doutora em Filosofia pela Universidade Católica de São Paulo e em Ciências Religiosas pela Universidade Católica de Louvain, na Bélgica. Lecionou por quase 20 anos no Instituto de Teologia do Recife, até ser imposta ao silêncio pelo Vaticano, em 1989. Atualmente, continua escrevendo e percorrendo o Brasil e diferentes países do mundo, ministrando cursos, proferindo palestras sobre hermenêutica feminista, novas referências éticas e antropológicas e os fundamentos filosóficos do discurso religioso. 
a questionar e a ressignificar as representações simbólicas do discurso da teologia tradicional. Em geral, esta produção apresenta uma dimensão política, por questionar as estruturas androcêntricas e se propor a repensar o lugar das mulheres no espaço socioeclesial visando, com isso, a construção de relações igualitárias de gênero e a afirmação positiva do sujeito feminino.

A crítica que se faz é que a Teologia Feminista, mesmo incorporando a categoria de gênero na perspectiva pós-estruturalista como ferramenta crítica na desconstrução dos significados de gênero, se manteve fortememente vinculada ao feminismo da diferença. Sem dúvida, essa teologia trouxe novos elementos para o universo teológico, porém se afirmou dentro dos pressupostos da Teologia da Libertação e, desde aí, reivindicou a igualdade e um lugar especial para as mulheres, afirmando que elas eram as "pobres entre os pobres". Isso no sentido de terem sido historicamente oprimidas por relações desiguais de gênero, de maneira específica, do acesso ao poder dentro da Igreja. Segundo Rodhen (1997), a Teologia Feminista ao priorizar um grupo social privilegiado operou um deslocamento de eixo dentro de um projeto universalista. Ou seja, as reivindicações passam pela categoria "mulher" que tem um substrato concreto muito mais irrefutável que a categoria mais genérica "o pobre". O discurso da Teologia Feminista, mesmo sendo "pretensamente mais igualitário e universalizante, está centrado dentro da lógica da oposição dual entre homens e mulheres, ou masculino e feminino", (Rodhen,1997: 96), sem muito contemplar as diferenças dentro da diferença, que constroem hierarquias de poder intragênero. Tais questões tem sido as preocupações das teorias mais contemporâneas da diferença ${ }^{36}$.

Finalmente, lembramos que a crítica feminista não se restringe às áreas de conhecimento que aqui foram mencionadas, mas perpassa todas as ciências e as humanidades, uma vez que essas áreas, em geral, ainda são masculinas. Desse modo, creio que a afirmação que segue inquieta as teóricas feministas de diferentes áreas do conhecimento.

"O desejo de recuperar a escrita feminista das mulheres pode, certamente, fundamentar-se, mais em um compromisso político de recuperar as vozes que as mulheres perderam, do que uma reivindicação epistemológica para a verdade necessária do que é falado por essas vozes. Essa discussão mantém uma distinção entre os textos dos homens e das mulheres - não porque as opiniões das mulheres da modernidade são sempre mais precisas do que as dos homens, mas porque a crítica feminista éo compromisso de dar, pelo menos, o mesmo peso aos pontos de vista e uma atenção especial às especificidades características da escrita das mulheres. Esta especificidade não deve ser vista simplesmente como interna de um texto, mas sim, ela é fundamentalmente modelada por significados particulares e os efeitos que daí resultam

36 Na produção mais contemporânea de muitas teólogas feministas constata-se a adesão pelas tendências teóricas do feminismo contemporâneo, que problematizam a noção englobante do "feminino"e incluem as intersecções com outros marcadores sociais tais como: classe, preferência sexual, religião, cultura, etnia, que geram hierarquias de poder e de desigualdade social. Entretanto, nossa pesquisa de doutorado mostra que quando as mulheres objetivam se legitimarem sujeitos femininos de saber teológico elas apelam para a perspectiva da valorização do "feminino"e de sua contribuição específica, como estratégia política de reconhecimento positivo da diferença e para reivindicar uma justa e igual redistribuição do poder 
para discursos públicos de autoria feminina. O gênero de autoria é um fator crucial que, em geral, influencia a circulação e a recepção do sentido textual" (Felski 1995: 33. Tradução da autora).

Evidentemente, o argumento de Felski se remete também ao campo da teologia, já que essa realidade pode ser percebida na crítica feminista à teologia tradicional. Tal questão, nos leva a considerar que a produção acadêmica resultante de uma crítica feminista, que evidenciamos na arte, na literatura e na teologia, integra a grande rede dos processos de reinterpretação e de desconstrução dos discursos construídos na vertente androcêntrica.

Praticamente em toda a sua obra Felski (1995) procura identificar e analisar algumas das representações mais universais da "mulher" e da modernidade, que se repetem dentro e, às vezes, nas fronteiras culturais e nos campos discursivos, cujos traços se estendem para além do século XIX. Sem dúvida, de igual maneira as representações de gênero contidas no discurso teológico tradicional, produziram comportamentos e hierarquias socioeclesiais, cujos traços, ainda hoje, se fazem notar.

\section{CONSIDERAÇÕES FINAIS}

No presente trabalho buscamos aprofundar e comparar aspectos relacionados à crítica feminista ao pensamento androcêntrico que, neste caso, se focou nos relatos literários sobre a modernidade, analisados por Felski (1995), e na teologia católica tradicional, como um discurso religioso e masculino fundado na tradição e na revelação cristã.

O pensamento científico, histórico, literário, teológico, entre outros, construído a partir da visão de um sujeito universal: masculino, heterossexual, branco, ocidental e de classe média, produziu determinadas representações de mundo que, nos termos de Simone de Beauvoir (1949), acabou por se confundir com a "verdade absoluta". Assim, o cânone das disciplinas acadêmicas foi sendo constituído por um determinado conhecimento, tido como "legítimo", em contraposição à exclusão e a marginalização de outros sujeitos históricos que, mesmo na invisibilidade, sempre participaram dos processos de construção da modernidade e da produção e expansão do cristianismo. Essa participação, no sentido de Adelman (2009), ocorreu por meio de uma troca desigual, seja por processos de dominação ou de resistência.

Tanto nos relatos sobre a modernidade como nas narrativas teológicas se notam claramente construções orientadas pela norma masculina, cujos discursos ao serem reproduzidos pelas instituições de ensino acadêmico ou eclesial, produziram efeitos nas relações sociais de gênero. Ou seja, no processo de estruturação e hierarquização de papéis sociais, as representações simbólicas, inscritas no discurso androcêntrico, reforçaram e legitimaram a supremacia do sujeito masculino, como o verdadeiro representante da sociedade moderna e, no universo da teologia, como o único representante da divindade. As ações históricas das mulheres foram invisibilizadas e elas foram desqualificadas para a liderança pública e para a produção de saberes. Nesse 
contexto, somente o gênero masculino se consituiu sujeito de enunciação e essa" $v o z$ universal" foi quem descreveu o "outro", que nesse caso se trata da figura histórica da "mulher", como um ser inferior, impacaz de atividade intelectual, apta somente para funções de ordem privada, como a da reprodução e a do "serviço ao Outro", no sentido de Simone de Beauvoir. Desse modo, a cultura patriarcal permitiu que tais discursos, tidos como "verdadeiros e absolutos" descrevessem as mulheres e o seu espaço social, segundo as experiências e os interesses do sujeito masculino.

Por esse motivo, destaca-se a importância da década de 1960, no final do século $X X$, quando surgiram os novos movimentos socioculturais, voltados não só para a reivindicação da igualdade social, mas também para a afirmação e reconhecimento de identidades culturais que eram "marginais". Nesse contexto, registra-se a emergência de vozes historicamente silenciadas, tidas como "subalternas", que agora começaram a se fazer ouvir. São vozes que surgiram de processos de reflexividade, de resistência política e da consciência de ter participado de uma história comum de invisibilidade e de exclusão social e eclesial, que era legitimada pelos discursos hegemônicos. No contexto social, isso ocorreu por meio da mobilização e da luta por direitos iguais e de afirmação da alteridade. Já, no universo acadêmico, destaca-se a crítica ao pensamento masculino que havia produzido situações de invisibilidade, de discriminação sexista e de desigualdade social de gênero.

Nesse sentido, as autoras feministas de diferentes áreas acadêmicas participaram da mesma tarefa crítica de desconstrução da lógica de gênero da ordem simbólica masculina e de construção de novos significados para as representações inscritas nos discursos androcêntricos. Para isso, elas tomaram como referência as experiências situadas das próprias mulheres, trazendo uma contribuição significativa para ciências humanas e sociais, ou seja, elas produziram o que se chamou de crítica feminista, colocando em pauta a reformulação das "grandes narrativas" e apontando novas possibilidades para a produção do conhecimento. Convém destacar que as autoras feministas da área da teologia e das ciências da religião compartilharam desse mesmo processo, já que a sua produção veio se alinhar com as críticas epistemológicas que questionaram a validade das pretensões universalistas do pensamento teológico hegemônico.

No conjunto desse processo histórico-acadêmico, que se fez visível a partir da década de 1960, em diferentes áreas do saber, a tarefa da crítica feminista produziu novas narrativas científicas, literárias, históricas e teológicas, as quais desvendaram a outra parte da história que não havia sido narrada pelo "sujeito masculino". Evidentemente, a crítica feminista foi fundamental no processo de desconstrução e de ressignificação dos "mitos" e signos que reproduziram, ao longo da história, relações de gênero desiguais. Isso, consequentemente, também contribuiu com a reinvenção ou afirmação positiva das subjetividades femininas, pautadas em novos modelos discursivos de gênero.

No entanto, a produção desses novos discursos tem encontrado resistência no universo acadêmico, justamente por desafiar a construção de uma nova cultura, não mais baseada na ordem dicotômica e hierárquica, geradora de discriminação e de exclusão 
social, mas baseada na inclusão e na participação igualitária de sujeitos masculinos e femininos, nos processos sociais. No mundo acadêmico, essa resistência aparece não só pelo fato de que os estudos feministas e de gênero ainda são considerados de "segunda categoria", mas, sobretudo, pela não inclusão de bibliografias feministas na grade curricular, no conjunto dos temas considerados importantes para cada área do saber. A socióloga Miriam Adelman (2009) apontou essa problemática dentro do campo sociológico, no entanto, essa situação ocorre também no universo do saber teológico, conforme se constatou em nossa pesquisa de doutorado. Com isso, não pretendemos generalizar, uma vez que existem alguns pensadores, do universo masculino, que têm inserindo em sua produção acadêmica, as categorias de análise que emergiram da teoria feminista, isso tanto na teologia como em outras áreas de saber. Entretanto, esses intelectuais são uma pequena minoria e, nem sempre adotam uma perspectiva mais radical.

Apesar do caminho já trilhado na releitura crítica de saberes, que foram produzidos desde a perspectiva masculina, há, ainda, muito por se fazer, uma vez que a ciência, a literatura, a história e a teologia seguem sendo masculinas, no sentido do que foi mencionado neste trabalho. Nosso estudo de doutorado tem mostrado que, no universo teológico, as mulheres docentes estão criando estratégias de resistência política perante os discursos hegemônicos, mesmo que, muitas vezes, isso ocorre de maneira contraditória. Mesmo sem provocar grandes mudanças nas estruturas acadêmicas, elas produzem uma ética de si e se legitimam como sujeitos femininos de saber teológico, mostrando que são dotadas de razão e que, também, podem dar uma contribuição especial para o campo do saber teológico.

Elas produzem processos de resistência, superam barreiras de gênero e abrem "novas portas" e possibilidades para as mulheres; legitimam-se como um sujeito de saber; constroem a sua cidadania eclesial se afirmando como um sujeito de direitos, por passar pelos mesmos processos de qualificação e de formação acadêmica de seus pares. Com isso, essas mulheres se distanciam dos modelos de gênero que foram reproduzidos pelo saber teológico, durante um longo período da história. Entretanto, essa trajetória vem sendo construída não sem desafios e tensões. Há, ainda, resistência por parte de seus pares masculinos em relação à produção teológica baseada nos estudos de gênero e na teoria feminista.

Finalmente, podemos afirmar que tanto a Teologia Feminista como outros saberes feministas produzidos pelas mulheres, nas distintas áreas acadêmicas, por sua perspectiva política e pelas tensões que vêm provocando no campo dos saberes, se configuram ao que Boaventura (2000) denomina de "conhecimento emancipatório" construído a partir de tradições epistemológicas marginais da modernidade, ou seja, é um "conhecimento prudente para uma vida decente". Tal afirmação se deve porque o saber que elas produzem constrói novos significados para as subjetividades femininas e apresenta uma proposta engajada de transformação das relações sociais de gênero e das estruturas androcêntricas, que ainda produzem discriminação de raça, sexo, gênero, cultura... Isso tem a ver com uma proposta de humanização nas relações e de emancipação cidadã 
de sujeitos que ficaram marginais, no campo da produção do saber, ou, nos termos de Boaventura Santos, de uma vida mais decente, para quem sempre foi considerado o "Outro", o "Inferior" e que agora emerge como um novo sujeito, também dotado de razão, desafiando a lógica generizada dos saberes literários e teológicos.

\section{REFERÊNCIAS BIBLIOGRÁFICAS}

Adelman. Miriam (2009): A Voz e a Escuta: Encontros e desencontros entre a teoria feminista e a sociologia contemporânea. São Paulo: Editora Blucher Ltda.

Barret, Michele (1999): "As palavras e as coisas: materialismo e o método na análise feminista contemporânea", in Revista Estudos Feministas, Florianópolis, CFH/UFSC, v.7, n. 1/2, p. 109-126.

Butler, Judith (2003): Problemas de gênero: feminismo e subversão da identidade. Rio de Janeiro: Civilização Brasileira.

Beauvoir, Simone de (1949): O segundo sexo: fatos e mitos (Vol.1). São Paulo: Circulo do Livro.

Brancher, Mercedes (2009): "Em Maria de Nazaré Deus se Manifesta", in Brancher, Mercedes; Domenzi, Maria Cecília (Org): Maria entre as mulheres: Perspectiva de uma Mariologia feminista libertadora, p. 55-74. São Leopoldo,RS: CEBI/Paulus.

Brunelli, Delir (2000): "Teologia e Gênero", in Suzin, Luiz Carlos (org): Sarça Ardente Teologia na América Latina: Prospectivas, p. 209-221. São Paulo: Paulinas.

Chassot, Atico (2009): A Ciência é masculina? São Leopoldo - RS: Editora Unisinos, $4^{a}$ ed.

Connell, Robert W. (1995): "Políticas da masculinidade", in Educação e Realidade, Porto Alegre, UFRG, v. 20, n.2, p.185-206. jul./dez.

Daly, Mary (1985): The Church and the second sex. Londres: Harper Books. (1986): Beyond God the Father. Londres: The Women Press.

Felski, Rita (1995): The Gender of Modernity. London, England: Harvard University Press Cambridge.

Fiorenza, Elisabeth Schüssler (1995): Discipulado de Iguais: uma ekkesia-logia feminista crítica da libertação. Petrópolis: Editora Vozes.

(2000): Cristología feminista crítica: Jesus, hijo de Miriam, profeta de la Sabiduría. Madrid:Trota. 
- (2009): "Mariologia, ideologia de gênero e o disciplulado de iguais", in Brancher, Mercedes; Domenzi, Maria Cecília (Org): Maria entre as mulheres: Perspectiva de uma Mariologia feminista libertadora, p. 27-54. São Leopoldo - RS: CEBI/Paulus.

Gebara, Ivone (2006a): "Teologia feminista e a crítica da razão religiosa patriarcal: entrevista com Ivone Gebara", in Revista de Estudos Feministas. Florianópolis, vol.14 (1), Jan./Abr 294-304 (Entrevista concedida a Maria José Rosado-Nunes).

(2006b): "Pensar a rebeldia cristã a partir das relações de gênero". In Souza, Sandra Duarte de.(Org): Gênero e religião no Brasil: ensaios feministas, p.135-146. São Paulo: UMESP.

- (2008): Compartir los panes y los peces: cristianismo, teología y teología feminista. Montevidéu - Uruguay: Doble clic-Editoras.

Graf, Norma Blazquez (2010): "Epistemología Feminista: temas centrales”, in Graf, Norma Blazquez; Palacios. Fátima Flores; Everaldo, Maribel Ríos (Coord.). Investigación feminista: epistemología, metodología y representaciones sociales, p. 21-38. Ciudad de México, DF: UNAM/CEIICH.

Furlin, Neiva (2011): "Teologia feminista: uma voz que emerge nas margens do discurso teológico hegemônico", in Revista de Estudos da Religião, ano 11, n 01: 139-16.

Harding, Sandra (1996): Ciencia y feminismo. Madrid: Ediciones Morat,.

Higuet, Etiene A. (2005): "Teologia e modernidade: introdução geral", in Higuet, Etiene A. (Org). Teologia e modernidade, p. 9-31. São Paulo: Fonte Editorial.

Hoornaert, Eduardo (1991): O movimento de Jesus. São Paulo: Editora FTD.

Japiassu, Hilton. 'Porque a ciência já nasceu machista?' In: Ciências questões interpretativas. Aparecida SP: Editora Ideias e Letras, 2011. p.17-50.

Lauretis, Teresa de (1994): "A tecnologia de gênero", in Holanda, Eloísa Buarque de (Org.): Tendências e impasses: o feminismo como crítica da cultura, p. 206-242. Rio de Janeiro: Rocco.

Llanos, Gabriela Castellano (2010): Decidimos, hacemos, somos: discurso identidades de género y sexualidades. Cali, Colombia: Universidad del Vale.

Louro, Guacira L. (1999): Gênero, sexualidade e educação. 3. ed. Petrópolis: Editora Vozes.

Macedo, Ana Gabriela e AMARAL, Ana Luísa (2005): Dicionário da Crítica Feminista. Lisboa: Edições Afrontamento. 
Moore, Henrietta L. (2000). “Fantasias de Poder e Fantasias de Identidade: gênero, raça e violência", in Cadernos Pagu (UNICAMP), Campinas, v. 14, p.13-44.

Paz, Octavio. Soror Juana Ines de La Cruz: As armadilhas da fé. São Paulo: Editora Mandarim, 1998.

Rohden, Fabíola (1995): “O cristianismo como uma'novidade'esquecida - igualitarismos nos primórdios da igreja", in Mandrágora, ano 2, no 2: 30-48.

(1997): "Catolicismo e protestantismo: o feminismo como uma questão emergente", in Cadernos Pagu (UNICAMP), Campinas, v. 8/9, p. 51-97.

Santos, Boaventura Souza de (2000): A crítica da razão indolente: Contra o desperdício da experiência. São Paulo, Cortez.

Schiebinger, Londa (2001): O Feminismo mudou a ciência? Bauru - SP: EDUSC,

Scott, Joan W. (1990): "Gênero: uma categoria útil de análise histórica", in Revista Educação e Realidade. Porto Alegre: UFRGS, v.16. n.2, p.5-22, jul/dez.

Susin, Luiz Carlos (2006): "O estatuto epistemológico da teologia como ciência da fé e a sua responsabilidade pública no âmbito das ciências e da sociedade pluralista", in Revista Trimestral/Teocomunicação, Vol. 36, n. 153, p. 555-563.

Tepedino, Ana Maria (1985):"A mulher: aquela que começa a'desconhecer o seu lugar'", in Perspectiva Teológica, ano XVII, n 43: 375-379. 